\title{
Factors Influencing Upfront Single- and Multiple-Ovulation Incidence, Progesterone, and Luteolysis Before a Timed Insemination Resynchronization Protocol ${ }^{1}$
}

\author{
J. S. Stevenson, ${ }^{2}$ M. A. Portaluppi, and D. E. Tenhouse \\ Department of Animal Sciences and Industry, Kansas State University, Manhattan 66506-0201
}

\begin{abstract}
Our objectives were to determine relationships among factors influencing responses to the first $\mathrm{GnRH}$ injection in a timed artificial insemination (TAI) protocol and subsequent fertility after altering timing of the second $\mathrm{GnRH}$ injection and $\mathrm{AI}$ relative to $\mathrm{PGF}_{2 \alpha}$ injection. Replacement heifers $(\mathrm{n}=86)$ and 613 lactating cows previously inseminated were diagnosed not pregnant to form 77 breeding clusters spanning 36 mo. At not-pregnant diagnosis (d 0), females received $100 \mu \mathrm{g}$ of $\mathrm{GnRH}$, and then $7 \mathrm{~d}$ later, they received $25 \mathrm{mg}$ of $\mathrm{PGF}_{2 \alpha}$. Females in 2 treatments received GnRH $48 \mathrm{~h}$ (G48) after $\mathrm{PGF}_{2 \alpha}$ injection and TAI at the time of the second GnRH injection (G48 + TAI48) or $24 \mathrm{~h}$ later (G48 + TAI72). Females in the third treatment received GnRH $72 \mathrm{~h}$ after $\mathrm{PGF}_{2 \alpha}$ when inseminated $(\mathrm{G} 72+$ TAI72). Neither timing of GnRH nor time of AI altered TAI pregnancy rates (average of 20.4\%). Ovaries of females in 65 clusters were scanned on d 0 (first GnRH injection) and $7 \mathrm{~d}$ later $\left(\mathrm{PGF}_{2 \alpha}\right.$ injection). Ovarian structures were mapped and ovulation in response to the first GnRH injection was evaluated on $\mathrm{d} 7$. When estrus was detected before scheduled TAI, females were inseminated; otherwise, TAI conception of remaining females was based on timing of $\mathrm{GnRH}$ and $\mathrm{AI}$ in 3 treatments. On d 7, 1 or more new corpora lutea (CL) were detected in $43 \%$ of females and their pregnancy rate was subsequently greater (28 vs. $18 \%$ ) than those not ovulating. Follicle diameters on d 0 did not differ between females that did $(11.9 \pm 0.3 \mathrm{~mm})$ and did not $(11.8 \pm 0.4 \mathrm{~mm})$ subsequently ovulate in response to GnRH. Follicle diameter and number of follicles $\geq 5 \mathrm{~mm}$ increased with increasing lactation number, but decreased with increasing number of CL. Diameter of follicles in which more than 1 follicle ovulated decreased
\end{abstract}

\footnotetext{
Received June 23, 2007.

Accepted August 17, 2007.

${ }^{1}$ Contribution number 08-005-J from the Kansas Agricultural Experiment Station, Manhattan.

${ }^{2}$ Corresponding author: jss@k-state.edu
}

linearly from that in which only 1 follicle ovulated. Incidence of ovulation increased with increasing lactation number and total number of follicles $\geq 5 \mathrm{~mm}$, but decreased with increasing number of CL. Incidence of multiple ovulations (15\%) was greater in females having more follicles $\geq 5 \mathrm{~mm}$ and in those in early diestrus. Multiple ovulation did not occur in heifers, but was decreased in cows having more than $1 \mathrm{CL}$. In cows having more than $1 \mathrm{CL}$, luteal regression was reduced by 5.6 percentage units compared with those having 1 CL. In a TAI protocol, pregnancy rate was greater for females in early diestrus compared with females in other stages of the cycle, in those that ovulated after the first GnRH injection, in those having luteolysis, and in those inseminated during nonsummer months.

Key words: gonadotropin-releasing hormone, Ovsynch, ovulation, pregnancy rate

\section{INTRODUCTION}

Several factors are known to influence fertility of a timed AI (TAI) protocol in dairy cattle when a follicular wave is synchronized in an Ovsynch-like protocol (GnRH injection given $7 \mathrm{~d}$ before and $48 \mathrm{~h}$ after luteolysis is induced by $\mathrm{PGF}_{2 \alpha}$ ). Day of the estrous cycle at the onset of such protocols influenced incidence of ovulation and follicle diameter after the second ovulatory $\mathrm{GnRH}$ injection that followed $\mathrm{PGF}_{2 \alpha}$-induced luteolysis (Vasconcelos et al., 1999). In that study, cows treated between $\mathrm{d} 1$ and 4 of the estrous cycle had the smallest incidence of ovulation (23\%), followed by those between d 10 and 16 (54\%), d 17 to 21 (77\%), and d 5 to $9(96 \%)$. No information is available about diameters of follicles in cows that ovulated.

Cows in early ( 1 to 4 ) or late (d 17 to 21 ) portions of the estrous cycle at the first GnRH injection, however, had larger diameter ovulatory follicles $7 \mathrm{~d}$ later than those on $\mathrm{d} 5$ to 13 , whereas pregnancy rates were greatest for cows in which the Ovsynch protocol was initiated between $\mathrm{d} 5$ and $14(42 \%)$ and less for those on $\mathrm{d} 1$ to 4 and 14 to 21 (32\%; Vasconcelos et al., 1999). Because pregnancy rate is greater among cows that ovulated in 
response to the first GnRH injection (Vasconcelos et al., 1999), determining those variables that influence ovulation is essential to understanding the Ovsynch protocol. Little is known, however, about factors associated with ovulatory responses to the first $\mathrm{GnRH}$ injection that may include, in addition to the stage of the estrous cycle, ovarian follicular inventory, number of luteal structures, season, and lactation status.

Timing of the GnRH injection and AI influence TAI pregnancy rates. When $\mathrm{GnRH}$ was administered at 48 $\mathrm{h}$ after the $\mathrm{PGF}_{2 \alpha}$ injection of the Ovsynch protocol and cows were inseminated at $48,56,64,72$, or $80 \mathrm{~h}$ after $\mathrm{PGF}_{2 \alpha}$, pregnancy rates at first service were maximal at $64 \mathrm{~h}$ or $16 \mathrm{~h}$ after GnRH (Pursley et al., 1997). In lactating dairy cows inseminated after 2 presynchronizing injections of $\mathrm{PGF}_{2 \alpha}$ given $14 \mathrm{~d}$ apart (Presynch) in which the Ovsynch protocol was initiated $12 \mathrm{~d}$ after the second Presynch injection, females were treated with $\mathrm{GnRH}$ and various administration times of $\mathrm{GnRH}$ and TAI were tested. Those females treated with $\mathrm{GnRH}$ at $48 \mathrm{~h}$ after the $\mathrm{PGF}_{2 \alpha}$ injection of Ovsynch and inseminated at that time $\left(48 \mathrm{~h}\right.$ after $\left.\mathrm{PGF}_{2 \alpha}\right)$ or $24 \mathrm{~h}$ later (Cosynch48) had lower pregnancy rates than cows injected and inseminated at $72 \mathrm{~h}$ after $\mathrm{PGF}_{2 \alpha}$ (Cosynch72; Portaluppi and Stevenson, 2006). The obvious advantage of such treatments is the convenience of carrying out all hormonal injections and TAI at the same time of the day when cows are conveniently restrained by feed-line lockups.

Recently, similar treatments initiated $11 \mathrm{~d}$ after Presynch (Cosynch48 and Cosynch72), produced lesser pregnancy rates in dairy cows compared with administering $\mathrm{GnRH}$ at $56 \mathrm{~h}$ after $\mathrm{PGF}_{2 \alpha}$ and inseminating cows $16 \mathrm{~h}$ later ( $72 \mathrm{~h}$ after $\mathrm{PGF}_{2 \alpha}$; Brusveen et al., 2006). These results also were consistent in that study for cows in which these variations of the Ovsynch protocol were applied after a not-pregnant diagnosis.

The objective of our study was to examine various factors that influence the leading first $\mathrm{GnRH}$-induced ovulatory response and resulting pregnancy rates in conjunction with altered timing of the second $\mathrm{GnRH}$ injection and TAI.

\section{MATERIALS AND METHODS}

\section{Herd Management}

The experiment was conducted at the Kansas State University Dairy Teaching and Research Center (Manhattan) using 68 replacement Holstein heifers and 249 lactating cows (total of 86 inseminations in heifers and 613 in cows during $36 \mathrm{mo}$ ). Previously inseminated females in 77 biweekly (every other week) breeding clusters were diagnosed not pregnant between October 2002 and October 2005. Cows were housed in covered

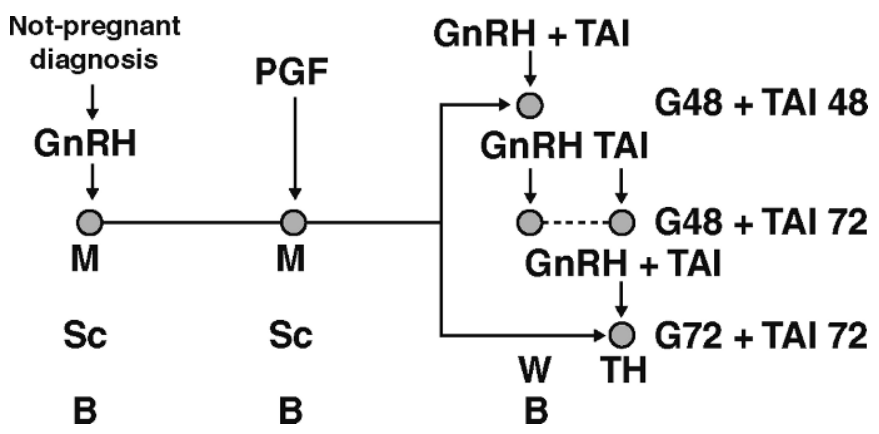

Figure 1. Experimental design of treatments. Nonpregnant females were injected with the first GnRH injection upon not-pregnant diagnosis and then $7 \mathrm{~d}$ later were injected with $\mathrm{PGF}_{2 \alpha}$. Females were injected with a second $\mathrm{GnRH}$ injection at $48 \mathrm{~h}$ after $\mathrm{PGF}_{2 \alpha}(\mathrm{G} 48)$ and inseminated at 48 (TAI48) or $72 \mathrm{~h}$ (TAI72) after $\mathrm{PGF}_{2 \alpha}$ or injected with GnRH at $72 \mathrm{~h}$ (G72) concurrent with timed AI (TAI72). M = Monday, $\mathrm{W}=$ Wednesday, $\mathrm{TH}$ = Thursday; $\mathrm{B}=$ blood sample to determine concentration of progesterone; $\mathrm{Sc}=$ ovarian scans by transrectal ultrasonography; GnRH = gonadotropin-releasing hormone; $\mathrm{PGF}=$ $\mathrm{PGF}_{2 \alpha} ;$ and TAI $=$ timed $\mathrm{AI}$.

free-stalls bedded with sand, and were fed a TMR at least twice daily that met or exceeded NRC (2001) requirements for lactating cows. The TMR consisted of $30 \%$ chopped alfalfa hay, $19 \%$ wet corn gluten meal, $15 \%$ corn silage, $9.3 \%$ whole cottonseed, $4.4 \%$ solventextracted soybean meal, $3.3 \%$ expeller soybean meal, $13 \%$ corn grain, $1.3 \%$ menhaden fish meal, $1 \%$ sugar cane wet molasses, and $3.7 \%$ mineral-vitamin premix. Cows had ad libitum access to fresh water. Pens housing lactating cows also had shade cloth covering part of the pens over the feed bunk and water applied by sprinklers 6 times per hour for $1 \mathrm{~min}$ along the feed line during May to October.

Replacement heifers were maintained in dirt lots with covered free-stalls and a concrete feed apron. They were fed a TMR consisting of chopped prairie or alfalfa hay, corn or milo grain, soybean meal, and minerals and vitamins to exceed NRC (2001) guidelines for growing heifers by 10 to $15 \%$ for all nutrients.

\section{Experimental Design}

Biweekly pregnancy diagnosis was conducted when females were between 30 and $43 \mathrm{~d}$ since last AI. Number of previous inseminations averaged $2.4 \pm 1.2$ (mean \pm SD; range 1 to 4). Lactating females ranged from 78 to 537 DIM, and averaged $190 \mathrm{~d}$. Replacement heifers ranged from 12 to 16 mo of age. Not-pregnant females were assigned randomly to 3 treatments (Figure 1). All females received $100 \mu \mathrm{g}$ of GnRH (Factrel, Fort Dodge Laboratories, Fort Dodge, IA, or Cystorelin, Merial Ltd., Iselin, $\mathrm{NJ}$ ) followed in $7 \mathrm{~d}$ by a $25-\mathrm{mg}$ injection of $\mathrm{PGF}_{2 \alpha}$ (Lutalyse, Pharmacia Animal Health, Kalamazoo, MI). 
Treatments consisted of injecting GnRH at $48 \mathrm{~h}(\mathbf{G 4 8})$ after $\mathrm{PGF}_{2 \alpha}$ and inseminating at that time (TAI48) or $24 \mathrm{~h}$ later (TAI72), or injecting $\mathrm{GnRH}$ and inseminating at 72 after $\mathrm{PGF}_{2 \alpha}(\mathbf{G 7 2}+$ TAI72). Females $(\mathrm{n}=98)$ that expressed estrus early before the scheduled TAI were inseminated and subsequently assigned a "0" for their pregnancy rate. Their conception rate was $26.5 \%$. All other information collected from some of these females was utilized in subsequent analyses depending on when they were inseminated.

Two inseminators performed all inseminations using frozen-thawed semen from multiple sources. Pregnancy was subsequently diagnosed between 30 and 43 after the treatment AI by using transrectal ultrasonography (5.0-MHz linear-array transducer, Aloka 500V; Corometrics Medical Systems, Inc., Wallingford, CT). A positive diagnosis included confirmation of a corpus luteum (CL) and uterine fluid, or an embryonic heart beat.

\section{Blood Collection and Ultrasonography of Ovaries}

Blood was collected from a coccygeal blood vessel at the not-pregnant diagnosis (d 0 ) and again at $\mathrm{d} 7$ and 9. Concentrations of progesterone were later determined in 14 RIA (Skaggs et al., 1984). Intra- and interassay coefficients of variation were 10 and $8.8 \%$ for a repeated pool of blood serum that averaged $3.92 \pm$ $0.06 \mathrm{ng} / \mathrm{mL}$.

Ultrasonography was conducted to monitor ovarian structures in the first 65 of the 77 clusters of females assigned to treatments (484 of 699 females). Ovarian follicles were mapped and sized (all follicles $\geq 5 \mathrm{~mm}$ were measured) on d 0 . Subsequently, numbers of follicles and luteal structures were quantified per ovary. On d 7, occurrence of ovulation of any follicle was recorded in response to the first $\mathrm{GnRH}$ injection given on d 0 .

\section{Definitions}

Stage of the estrous cycle was determined based on blood samples collected at not-pregnant diagnosis (d 0), d 7 (day of $\mathrm{PGF}_{2 \alpha}$ injection), and d 9. In blood samples collected on $\mathrm{d} 0$ and 7 , serum progesterone was classified as high $(\geq 1 \mathrm{ng} / \mathrm{mL})$ or low $(<1 \mathrm{ng} / \mathrm{mL})$. Subsequently, combinations of high and low on $d 0$ and 7 were used to classify stage of the cycle on $\mathrm{d} 0$ as early diestrus (high-high), late diestrus (high-low), or proestrus to metestrus (low-high).

In addition to classification of the stages of the estrous cycle, females were classified as having functional cystic ovaries. Diagnosis of functional ovarian cysts (follicular or luteal) was based on scanning information obtained on $\mathrm{d} 0$ and 7 , presence of at least 1 large structure $(>24$ $\mathrm{mm}$ ), and serum progesterone concentration. Of 51 such females, $19(37.3 \%)$ were removed from the cystic classification because a CL also was present on d 0 (4 of the 19 females ovulated a follicle in response to $\mathrm{GnRH}$ ). Twelve more females were removed from the cystic category because ovulation of at least 1 normal-sized follicle (11.6 to $21.3 \mathrm{~mm}$ ) occurred in response to $\mathrm{GnRH}$ on d 0 (3 of which ovulated 2 follicles each). The cystic structure was assumed nonfunctional in the preceding 31 females. The remaining 20 females (without a CL or did not ovulate after d 0 ) were classified as cystic.

Those classified as having luteal cysts (14 of 20) or cystic CL had at least 1 or more large $(>25 \mathrm{~mm}$; average $=32.3 \pm 1.3 \mathrm{~mm}$ ) structures in which a luteal tissue border surrounding the structure was visible by scanning, retrospective serum progesterone was $\geq 1 \mathrm{ng} / \mathrm{mL}$ (average $=2.7 \pm 0.4 \mathrm{ng} / \mathrm{mL}$ ), and the structure palpated very firm. Those classified as having follicular cysts $(6$ of 20) had 1 or more large $(>25 \mathrm{~mm}$; average $=32.5 \pm$ $5.0 \mathrm{~mm}$ ) structures without ultrasonographic evidence of luteal tissue border, retrospective serum progesterone was $<1 \mathrm{ng} / \mathrm{mL}$ (average $=0.5 \pm 0.1 \mathrm{ng} / \mathrm{mL}$ ), and the structure was very soft on palpation. In a few cases, palpation of the follicular structure resulted in its rupture.

Apparent anestrous cows were categorized as those having no CL at the not-pregnant diagnosis and low serum concentrations of progesterone in all 3 blood samples. Some of these females could have been in early proestrus, having low serum progesterone and had similarly reduced concentrations 7 and $9 \mathrm{~d}$ later.

\section{Statistical Analyses}

Continuous variables were analyzed by using PROC GLM (SAS Institute Inc., Cary, NC) to assess effects on diameter of the largest follicle (putative dominant follicle) identified at not-pregnant diagnosis. Models were constructed consisting of the following independent variables: treatment (G48 + TAI48, G48 + TAI72, and G72 + TAI72); lactation number $(0,1,2$, or 3 or more); number of CL ( 0,1 , or 2 or more); total number of follicles $\geq 5 \mathrm{~mm}$ in diameter $(0,1,2$, or 3 or more); incidence of ovulation ( 0 vs. 1 ) or incidence of multiple ovulation ( 0 vs. 1$)$; season of treatment insemination [winter (January to March), spring (April to June), summer (July to September), and autumn (October to December)], and number of previous inseminations (1, 2, 3 , or 4 or more) as a covariate.

Model 1 included factors listed previously plus day of the estrous cycle at the not-pregnant diagnosis. The estrous cycle or interovulatory interval was assumed to be $22 \mathrm{~d}$ in duration (Royal et al., 2000; Blevins et al., 2006), so day of the estrous cycle was calculated to be 
days since $\mathrm{AI}$ at not-pregnant diagnosis (range of 30 to $43 \mathrm{~d}$ ) minus $22 \mathrm{~d}$. Seven categories were constructed (days of cycle $\leq 9,10$ to 11,12 to 13,14 to 15,16 to 17 , 18 to 19 , and $\geq 20$ ). Model 2 replaced days of the estrous cycle in model 1 with luteal status at not-pregnant diagnosis. Luteal status was based on concentrations of progesterone on d $0(0=$ low or $1=$ high $)$. Model 3 replaced days of the estrous cycle in model 1 with cycling status (early diestrus, late diestrus, proestrus to metestrus, anestrus, or cystic) at not-pregnant diagnosis.

Bimodal data (incidence of ovulation, incidence of multiple ovulation, and pregnancy rates) were analyzed by using logistic regression (procedure GENMOD; SAS Institute Inc.). The same 3 models were constructed as described previously for analyzing follicular diameters. A reduced set of 3 models was run to assess effects on pregnancy rates in all females regardless of whether scanning information was collected. Those reduced models included treatment, lactation number, season, number of previous inseminations, with days of the estrous cycle, luteal status, or cycling status at the notpregnant diagnosis.

Polynomials were constructed to test for linear, quadratic, and cubic effects of lactation number, number of CL, and total numbers of follicles $\geq 5 \mathrm{~mm}$ in diameter. Other means were separated by the least-significant difference in procedure GLM or by $\chi^{2}$ in procedure GENMOD, when associated with a protected $F$-test $(P \leq$ $0.05)$.

\section{RESULTS AND DISCUSSION}

\section{Treatment Al Pregnancy Rates}

Pregnancy rates in all females did not differ based on timing of the second $\mathrm{GnRH}$ injection and $\mathrm{AI}$ (treatments; Table 1), but were reduced $(P<0.05)$ during summer compared with those during other seasons (Table 1). Pregnancy rates in a previous report (Portaluppi and Stevenson, 2005) were greater at first service for lactating cows in the G72 + TAI72 treatment compared with the other 2 treatments. In that study, estrous cycles in cows were presynchronized with 2 injections of $\mathrm{PGF}_{2 \alpha}$ given $14 \mathrm{~d}$ apart (Presynch), with the second Presynch injection administered $12 \mathrm{~d}$ before the onset of the 3 variations of the Ovsynch protocol similar to those tested in the present study. A recent report (Brussveen et al., 2006) indicated that administering the second GnRH injection at 56 rather than $48 \mathrm{~h}$ after $\mathrm{PGF}_{2 \alpha}$ and then inseminating $16 \mathrm{~h}$ later produced superior pregnancy rates for cows inseminated at first service after Presynch + Ovsynch as well as for those reinseminated after a not-pregnant diagnosis compared with similar treatments (G48 + TAI48 and G72 + TAI72) applied in the present study.
Table 1. Factors affecting timed AI pregnancy rates in all dairy cattle in the study

\begin{tabular}{|c|c|c|}
\hline Item & No. ${ }^{1}$ & $\begin{array}{l}\text { Percentage } \\
\text { pregnant }^{2}\end{array}$ \\
\hline \multicolumn{3}{|l|}{ Treatment $^{3}$} \\
\hline G48 + TAI48 & 222 & 21.1 \\
\hline G48 + TAI72 & 222 & 23.0 \\
\hline G72 + TAI72 & 218 & 17.0 \\
\hline Total & 662 & 20.4 \\
\hline \multicolumn{3}{|l|}{ Lactation number } \\
\hline 0 & 78 & 26.9 \\
\hline 1 & 255 & 20.4 \\
\hline 2 & 163 & 20.2 \\
\hline 3 or more & 166 & 17.5 \\
\hline \multicolumn{3}{|l|}{ Season } \\
\hline Winter & 183 & $29.5^{\mathrm{a}}$ \\
\hline Spring & 148 & $22.7^{\mathrm{a}}$ \\
\hline Summer & 185 & $7.9^{b}$ \\
\hline Autumn & 137 & $22.9^{\mathrm{a}}$ \\
\hline \multicolumn{3}{|l|}{ Ovarian-luteal status ${ }^{4}$} \\
\hline Early diestrus - No CL regression & 49 & $14.3^{\mathrm{ab}}$ \\
\hline Early diestrus - CL regression & 283 & $25.8^{\mathrm{ac}}$ \\
\hline Late diestrus - Early CL regression & 102 & $8.8^{\mathrm{b}}$ \\
\hline Proestrus to metestrus - No CL regression & 50 & $10.0^{\mathrm{b}}$ \\
\hline Proestrus to metestrus - CL regression & 121 & $30.6^{\mathrm{c}}$ \\
\hline Anestrus & 57 & $7.0^{\mathrm{b}}$ \\
\hline
\end{tabular}

${ }^{a-c}$ Means having different superscript letters differ $(P \leq 0.01)$.

${ }^{1}$ Number of observations (includes multiple observations of the same females).

${ }^{2}$ Timed AI pregnancy rate [includes 98 females inseminated early after detected estrus (conception rate $=26.5 \%$ ) before the appointed timed AI schedule]. Those inseminated early were assigned a "0" for pregnancy rate.

${ }^{3}$ Not-pregnant females were injected with $\mathrm{GnRH}$ upon not-pregnant diagnosis and then $7 \mathrm{~d}$ later were injected with $\mathrm{PGF}_{2 \alpha}$. Cows were injected with a second $\mathrm{GnRH}$ injection at $48 \mathrm{~h}$ after $\mathrm{PGF}_{2 \alpha}$ (G48) and inseminated at 48 (TAI48) or $72 \mathrm{~h}$ (TAI72) after $\mathrm{PGF}_{2 \alpha}$ or injected with $\mathrm{GnRH}$ at $72 \mathrm{~h}(\mathrm{G} 72)$ at the same time as timed AI (TAI72).

${ }^{4}$ Ovarian-luteal status at the time of the first GnRH injection. Blood samples were collected before first $\mathrm{GnRH}$ injection (d 0) and at $\mathrm{d} 7$ and 9 ( $2 \mathrm{~d}$ after $\mathrm{PGF}_{2 \alpha}$ injection). Serum progesterone was classified as high $(\mathrm{H}, \geq 1 \mathrm{ng} / \mathrm{mL})$ or low $(\mathrm{L},<1 \mathrm{ng} / \mathrm{mL})$ at each blood collection time to define status on d 0,7 , and 9: early diestrus - No corpus lueum (CL) regression (HHH); early diestrus - CL regression (HHL); late diestrus - early CL regression (HLL); proestrus to metestrus no CL regression (LHH); proestrus to metestrus - no CL regression (LHH); proestrus to metestrus - CL regression (LHL); and anestrus (LLL).

When ovarian-luteal status was examined based on stage-of-the-cycle at the first injection of GnRH and luteal status 7 and 9 d later, TAI pregnancy rates among early diestrous females with no CL regression, those in late diestrus having early CL regression, those in proestrus to metestrus with no CL regression, and those in anestrus were reduced (Table 1). Those females having luteal regression resulted in pregnancy rates more than double $(P<0.01)$ those without luteal regression $(27.2 \%, \mathrm{n}=404$ vs. $12.1 \%, \mathrm{n}=99)$, respectively.

\section{Ovulation Incidence}

Incidence of ovulation in response to the first $\mathrm{GnRH}$ injection averaged 43\% (236 of 550). Ovulation inci- 


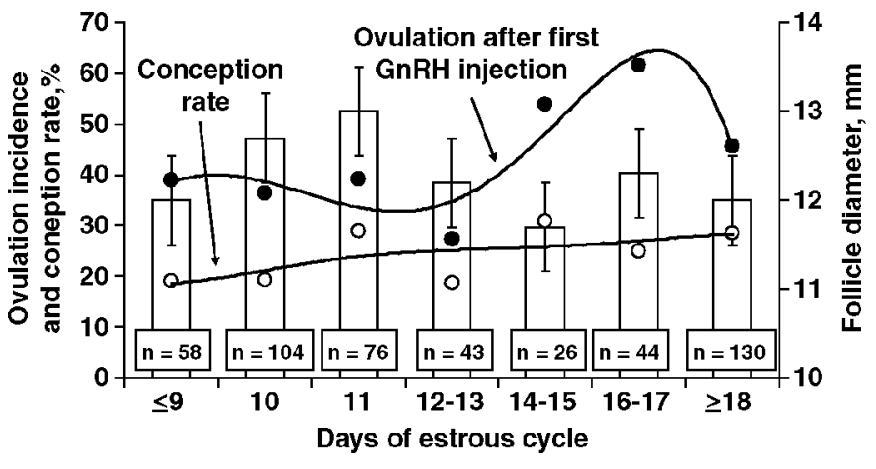

Figure 2. Relationship between ovulatory response to first $\mathrm{GnRH}$ injection of Ovsynch, diameter of follicles (open bars) that ovulated, day of the estrous cycle, and subsequent AI conception rate. A fifthorder polynomial $(P=0.05)$ was fitted to the ovulation-incidence curve, and a second-order polynomial $(P<0.05)$ was fitted to the conception rate curve. Days of estrous cycle were estimated by subtracting 22 from days since the previous AI when not-pregnant diagnosis was performed in dairy cattle.

dence differed $(P<0.05)$ in magnitude among days of the estrous cycle (range $=27.3$ to $61.5 \%$; Figure 2 ) and followed a pattern consistent with atresia of a dominant follicle associated with the first follicular wave and subsequent rise of a new dominant follicle of a subsequent follicular wave (Lucy et al., 1992). Pattern of ovulation incidence across days of the estrous cycle fit a fifthorder $(P<0.05)$ polynomial response curve.

Incidence of ovulation (43\%) in our report was less than that reported in 159 cows staged at various days of the estrous cycle (64\%; Vasconcelos et al., 1999). A reduced incidence of ovulation may be attributable to our cattle being further in milk ( $190 \pm 79 \mathrm{~d})$, and including nonlactating replacement heifers and cattle that had been previously inseminated, in contrast to the latter study, in which only lactating cows were studied before their first postpartum AI (56 \pm 16 DIM).

Nonlactating replacement heifers had the smallest incidence of ovulation (21.7\%), which is consistent with an earlier report (Pursley et al., 1995). As lactation number increased from 0 to 3 or more, ovulation incidence increased $(P<0.01)$ linearly (Table 2$)$. Season, however, had no effect on ovulatory response (Table 2 ).

Luteal status and concentrations of progesterone influenced incidence of ovulation. Fewer $(P<0.001)$ follicles ovulated in females having elevated $(\geq 1 \mathrm{ng} / \mathrm{mL})$ serum progesterone just before GnRH injection than in those females having reduced $(<1 \mathrm{ng} / \mathrm{mL})$ concentrations $(36.1 \%, \mathrm{n}=368$ vs. $56.4 \%, \mathrm{n}=181)$, respectively. This reduction was further substantiated by a linear $(P<0.01)$ decrease in ovulatory response of females having 0,1 , or 2 or more CL before GnRH injection (Table 2). Early postpartum lactating cows having no CL (anovular) ovulated at a greater frequency in re- sponse to GnRH than those having a CL (Gümen et al., 2003).

Females in late diestrus at first GnRH injection had the smallest $(P<0.05)$ incidence of ovulation $(30.1 \%)$ compared with those in early diestrus (49.3\%) and those in proestrus to metestrus (65\%; Table 2). Our study was not designed to make comparisons of ovulation incidence based on stage of the estrous cycle at the first GnRH injection; however, we observed more ovulations in cows having reduced concentrations of progesterone (proestrus to metestrus), which was not consistent with a previous report (Vasconcelos et al., 1999). Incidence of ovulation increased $(P<0.01)$ linearly and quadratically as number of ovarian follicles $\geq 5 \mathrm{~mm}$ in diameter increased from 1 to 3 or more (Table 2).

Timed AI pregnancy rates among females in which ovaries were scanned, regardless of whether they ovulated in response to the first $\mathrm{GnRH}$ injection, were not influenced by treatment, ovarian status, stage of cycle, lactation number, or number of CL at the time of the first GnRH injection (Table 2). Pattern of conception rates over days of the estrous cycle was fitted to a second-order polynomial response curve $(P<0.05)$ and tended to parallel the pattern of ovulation incidence (Figure 2). Females that ovulated in response to the first GnRH injection had subsequently greater $(P<$ $0.05)$ pregnancy rates than females that did not ovulate $(27.9 \%, \mathrm{n}=216$ vs. $18 \%, \mathrm{n}=294)$, consistent with previous observations (Vasconcelos et al., 1999). When incidence of ovulation in the model was replaced by the number of GnRH-induced ovulations ( $0,1,2$ or more), pregnancy rates were $18 \%(\mathrm{n}=294), 28.1 \%(\mathrm{n}=192)$, and $27.3 \%(\mathrm{n}=34)$, respectively. No difference in subsequent TAI pregnancy rate was detected among those females that ovulated 1 vs. 2 or more follicles in response to the first GnRH injection.

\section{Diameter of Largest Follicle}

Diameter of the largest follicle before the first GnRH injection, regardless of whether it ovulated, did not vary significantly among days of the estrous cycle. As lactation number and number of follicles $\geq 5 \mathrm{~mm}$ in diameter increased, diameter of the largest follicle increased $(P$ $<0.01)$ linearly, and quadratically $(P<0.01)$ in the case of follicle numbers (Table 2). As the number of CL increased $(P<0.001)$, the diameter of the largest follicle decreased linearly. Neither season, concentration of progesterone before $\mathrm{GnRH}$ injection $(<1 \mathrm{ng} / \mathrm{mL}$ : $12.4 \pm$ 0.3 vs. $\geq 1 \mathrm{ng} / \mathrm{mL}: 12.3 \pm 0.3 \mathrm{~mm}$ ), or ovarian status influenced diameter of the largest follicle (Table 2). Diameter of the largest follicle for those that ovulated or failed to ovulate in response to the first $\mathrm{GnRH}$ injection did not differ (Table 2). 
Table 2. Factors influencing incidence of ovulation in response to the first GnRH injection of Ovsynch, diameter of the largest follicle in ovarian-scanned dairy cattle, and pregnancy rate

\begin{tabular}{|c|c|c|c|c|}
\hline Item $^{1}$ & No. $^{2}$ & Ovulation, \% & $\begin{array}{l}\text { Largest follicle } \\
\text { diameter, mm }\end{array}$ & $\begin{array}{l}\text { Pregnancy } \\
\text { rate, \% }\end{array}$ \\
\hline \multicolumn{5}{|c|}{ Ovarian status at not-pregnant diagnosis ${ }^{3}$} \\
\hline Anestrus & 20 & 0.0 & $10.5 \pm 0.9$ & 5.6 \\
\hline Cystic & 18 & 0.0 & $11.8 \pm 0.9$ & 31.3 \\
\hline Proestrus to metestrus & 138 & $65.0^{\mathrm{a}}$ & $12.5 \pm 0.3$ & 22.7 \\
\hline Early diestrus & 216 & $49.3^{\mathrm{b}}$ & $12.1 \pm 0.3$ & 26.9 \\
\hline Late diestrus & 157 & $30.1^{\mathrm{c}}$ & $12.4 \pm 0.3$ & 19.9 \\
\hline \multicolumn{5}{|l|}{ No. of corpora lutea (CL) } \\
\hline 0 & 162 & $56.2^{4}$ & $13.4 \pm 0.4^{4}$ & 19.7 \\
\hline 1 & 304 & 38.5 & $11.7 \pm 0.4$ & 24.7 \\
\hline 2 or more & 83 & 32.5 & $10.4 \pm 0.5$ & 18.8 \\
\hline \multicolumn{5}{|c|}{ Total no. of follicles $\geq 5 \mathrm{~mm}$} \\
\hline 0 & 28 & - & $5.1 \pm 0.7^{4,5}$ & 30.8 \\
\hline 1 & 191 & $30.9^{4,5}$ & $13.5 \pm 0.4$ & 22.9 \\
\hline 2 & 212 & 47.2 & $14.4 \pm 0.3$ & 22.7 \\
\hline 3 or more & 118 & 64.4 & $14.6 \pm 0.4$ & 18.8 \\
\hline \multicolumn{5}{|l|}{ Ovulation of largest follicle } \\
\hline No & 294 & - & $11.9 \pm 0.3$ & $27.9^{\mathrm{a}}$ \\
\hline Yes & 216 & - & $11.8 \pm 0.4$ & $18.0^{\mathrm{b}}$ \\
\hline \multicolumn{5}{|l|}{ Lactation number } \\
\hline 0 & 61 & $21.3^{4}$ & $11.2 \pm 0.5^{4}$ & 26.2 \\
\hline 1 & 208 & 38.9 & $11.5 \pm 0.4$ & 23.3 \\
\hline 2 & 150 & 49.3 & $12.1 \pm 0.4$ & 20.9 \\
\hline 3 or more & 130 & 51.5 & $12.7 \pm 0.4$ & 20.3 \\
\hline \multicolumn{5}{|l|}{ Season } \\
\hline Winter & 178 & 43.8 & $12.2 \pm 0.4$ & $30.4^{\mathrm{a}}$ \\
\hline Spring & 142 & 38.0 & $11.9 \pm 0.4$ & $22.6^{\mathrm{a}}$ \\
\hline Summer & 136 & 47.8 & $11.3 \pm 0.5$ & $8.7^{\mathrm{b}}$ \\
\hline Autumn & 93 & 40.9 & $12.1 \pm 0.5$ & $25.8^{\mathrm{a}}$ \\
\hline
\end{tabular}

${ }^{\mathrm{a}-\mathrm{c}}$ Means within item having different superscript letters differ $(P \leq 0.05)$.

${ }^{1}$ Factors assessed at the not-pregnant diagnosis ( $\mathrm{d} 0$ ).

${ }^{2}$ Number of observations (includes multiple observations of the same females).

${ }^{3}$ Blood samples were collected at not-pregnant diagnosis (d 0) and at $\mathrm{d} 7$ and 9 ( $2 \mathrm{~d}$ after pregnancy diagnosis and $\mathrm{PGF}_{2 \alpha}$ injection). In the first 2 blood samples, serum progesterone was classified as high $(\geq 1$ $\mathrm{ng} / \mathrm{mL})$ or low $(<1 \mathrm{ng} / \mathrm{mL})$. Anestrous cows had no CL at the not-pregnant diagnosis and low progesterone in all 3 blood samples, whereas proestrus to metestrus = low-high, early diestrus $=$ high-high, and late diestrus = high-low. Cystic diagnosis was based on scanned structure $>25 \mathrm{~mm}$ in diameter and absence of a CL. Largest follicle diameter in the table excluded the cystic structure.

${ }^{4}$ Linear $(P \leq 0.01)$.

${ }^{5}$ Quadratic $(P \leq 0.01)$.

\section{Multiple Ovulation}

Incidence of multiple ovulation averaged $14.9 \%$ (35 of 235) in response to the first GnRH injection, but none occurred in heifers. In all but 1 case ( 3 ovulations), multiple ovulation was limited to 2 follicles. Ovulation of the 2 largest follicles occurred in 27 of 35 (77.1\%) cases; ovulation of the first- and third-largest follicles occurred in 1 case (2.9\%); ovulation of the second- and third-largest follicles occurred in 6 of 35 (17.1\%) cases; and ovulation of the 3 largest follicles occurred once (2.9\%; Table 3$)$.

Mean diameter of the 3 largest follicles that ovulated as singles or multiples is shown in Table 3 . The largest ovulating follicle was greater $(P<0.05)$ in diameter than the second- and third-largest follicles that ovulated. The third-largest follicle tended $(P<0.10)$ to be smaller in diameter than the second follicle in cows having single and multiple ovulations. In the case of single ovulations, the largest follicle ovulated $72.6 \%$ of the time followed by the second-largest follicle (32.5\%), and then the third-largest follicle (10.2\%). In nonlactating dairy cows (Mann et al., 2007) and in beef cows selected for twinning (Echternkamp, 2000), both with limited observations, no difference was detected in ovulatory follicle diameter between cows having spontaneous single and multiple ovulations. In contrast, diameter of the largest- and second-largest follicles induced to ovulate in the present study was clearly different from one another (Table 3).

For multiple-ovulating cows, the second-largest follicle ovulated $97.1 \%$ of the time followed by the largest $(82.9 \%)$ and third-largest (33.3\%) follicles. As expected, the second- or third-largest follicles in multiple-ovulating cows ovulated more often $(P<0.05)$ than in single- 
Table 3. Follicular characteristics and ovulation incidence associated with single or multiple ovulations

\begin{tabular}{lllcc}
\hline & & \multicolumn{3}{c}{ Follicle $^{1}$} \\
\cline { 3 - 4 } Item & Ovulation & \multicolumn{1}{c}{ Largest } & Second & Third \\
\hline \multirow{2}{*}{ Ovulation incidence $^{2}, \%$} & Single & $72.6(201)^{3}$ & $32.5^{\mathrm{a}}(154)$ & $10.2^{\mathrm{a}}(49)$ \\
& Multiple & $82.9(35)$ & $97.1^{\mathrm{b}}(35)$ & $33.3^{\mathrm{b}}(24)$ \\
& Total & $74.2(236)$ & $44.4(189)$ & $17.8(73)$ \\
Ovulated follicle diameter, mm & Single & $14.6 \pm 0.3^{\mathrm{x}}(155)$ & $12.1 \pm 0.5^{\mathrm{y}}(50)$ & $10.5 \pm 1.4^{\mathrm{y}, \mathrm{z}}(5)$ \\
& Multiple & $14.1 \pm 0.6^{\mathrm{x}}(29)$ & $11.7 \pm 0.6^{\mathrm{y}}(34)$ & $9.8 \pm 1.1^{\mathrm{y}, \mathrm{z}}(8)$ \\
& Total & $14.4 \pm 0.4^{\mathrm{x}}(174)$ & $11.9 \pm 0.3^{\mathrm{y}}(84)$ & $10.2 \pm 0.9^{\mathrm{y}, \mathrm{z}}(13)$ \\
Follicles ovulated $<10 \mathrm{~mm},{ }^{4} \%$ & Single & $90.9(11)$ & $18.2^{\mathrm{a}}(55)$ & $6.7(30)$ \\
& Multiple & $100.0(1)$ & $100.0^{\mathrm{b}}(9)$ & $20.0(10)$ \\
& Total & $91.7(12)$ & $29.7(64)$ & $10.3(40)$ \\
\hline
\end{tabular}

${ }^{\mathrm{a}, \mathrm{b}}$ Means within follicle category having different superscript letters differ $(P \leq 0.05)$.

${ }^{\mathrm{x}-\mathrm{z}}$ Means between follicle categories having different superscript letters differ $(P \leq 0.05)$.

${ }^{1}$ Follicles ( $\geq 5 \mathrm{~mm}$ in diameter) were ranked in order of size by using ultrasonography before the first injection of GnRH.

${ }^{2}$ Percentage of time either the largest, second-largest, or third-largest follicle ovulated in response to the first GnRH injection for single ovulations or percentage time multiple ovulations involved any combination of the largest, second-largest, and third-largest follicle.

${ }^{3}$ Number of observations are in parentheses.

${ }^{4}$ Percentage of ovulated follicles that were $<10 \mathrm{~mm}$ in diameter. For single ovulation, $22.9 \%$ of 96 total follicles were $<10 \mathrm{~mm}$ in diameter compared with $60 \%$ of 20 follicles $<10 \mathrm{~mm}$ (multiple ovulations).

ovulating cows. Overall, fewer $(22.9 \% ; P<0.01)$ follicles ( $\mathrm{n}=96$ ) that ovulated as singles were $<10 \mathrm{~mm}$ in diameter at the time of $\mathrm{GnRH}$ injection compared with $60 \%$ of 20 follicles that ovulated as multiples (Table 3).

As the number of ovarian follicles $\geq 5 \mathrm{~mm}$ in diameter increased from 1 to 3 or more, incidence of multiple ovulation increased $(P<0.001)$ linearly (Table 4$)$, which is consistent with findings in beef cattle selected for twinning and known to produce a greater than normal frequency of twins (Echternkamp et al., 2004). Induced multiple ovulation was quite variable among cows in different lactation groups (Table 4) and tended $(P=$ 0.07 ) to fit a third-order polynomial response curve. Some of this variation is likely associated with greater incidence of double ovulation in cows of greater milk yield (Fricke and Wiltbank, 1999). Parity of dam is clearly associated with increased spontaneous double ovulation and twinning rate because most twins result from multiple ovulations (Wiltbank et al., 2000; Mann et al., 2007). The curvilinear response for induced multiple ovulations observed in the present study as lactation number increased is also consistent with the largest increase in twinning rate observed between first and second calvings (Wiltbank et al., 2000). When cows having no CL ovulated in response to the first GnRH injection, the greatest incidence of multiple ovulation was detected, whereas it tended (quadratic; $P=0.06$ ) to decrease for those having $1 \mathrm{CL}$, and then increased for those having 2 or more CL. This greater incidence of multiple ovulation in cows having no CL is consistent with another report (Gümen et al., 2003). Females in early diestrus had more $(P<0.06)$ induced multiple ovulation than those in late diestrus; those staged in proestrus to metestrus were intermediate (Table 4). We were not able to detect a seasonal influence on incidence of multiple ovulation, although numerically, more multiple ovulations seemed to occur during summer.

Double ovulation in response to the first $\mathrm{GnRH}$ injection in early postpartum lactating cows was 10 -fold greater in anovular than ovular cows, but was not different after a second $\mathrm{GnRH}$ injection given $9 \mathrm{~d}$ later (48 $\mathrm{h}$ after $\mathrm{PGF}_{2 \alpha}$ ) as part of the Ovsynch protocol (Gümen et al., 2003). For double ovulation to occur naturally, follicle deviation must have failed to occur (Wiltbank et al., 2000). Codominant follicles occur rather infrequently to produce double ovulation, but are more common in cows of greater milk production (Fricke and Wiltbank, 1999) and in anovular cows (Wiltbank et al., 2000). Although milk yield may be a predisposing factor, spontaneous double ovulation is still rather large (28.3\%) in nonlactating cows as well (Mann et al. 2007), suggesting other predisposing factors. Selection of a dominant follicle occurs when reaches a diameter of 8.5 $\pm 1.2 \mathrm{~mm}$, acquires LH receptors on granulosa cells, and secretes greater amounts of estradiol (Ginther et al., 2003). To induce multiple ovulation pharmacologically with GnRH (via GnRH-induced LH secretion), follicles likely have those same minimal characteristics. Clearly, induced multiple ovulation occurred more frequently in females having more follicles $\geq 5 \mathrm{~mm}$, and fewer concurrent luteal structures (Table 4).

In females in which 1 or more follicles ovulated, pregnancy rates only significantly differed among seasons (Table 4), whereas number of CL, total number of folli- 
Table 4. Factors affecting single- and multiple-ovulatory responses to the first GnRH injection of Ovsynch, diameter of ovulatory follicles in ovarian-scanned dairy cattle, and pregnancy rate

\begin{tabular}{|c|c|c|c|c|}
\hline Item $^{1}$ & $\mathrm{No}^{2}$ & $\begin{array}{c}\text { Multiple } \\
\text { ovulation, }{ }^{3} \%\end{array}$ & $\begin{array}{l}\text { Diameter of ovulatory } \\
\text { follicle(s), mm }\end{array}$ & $\begin{array}{l}\text { Pregnancy } \\
\text { rate, } \%\end{array}$ \\
\hline \multicolumn{5}{|c|}{ Ovarian status at not-pregnant diagnosis ${ }^{4}$} \\
\hline Anestrus & 0 & - & - & - \\
\hline Cystic & 0 & - & - & - \\
\hline Proestrus to metestrus & 102 & $14.7^{\mathrm{ab}}$ & $14.1 \pm 0.5$ & 22.2 \\
\hline Early diestrus & 68 & $20.6^{\mathrm{b}}$ & $13.7 \pm 0.5$ & 32.3 \\
\hline Late diestrus & 65 & $9.2^{\mathrm{a}}$ & $14.1 \pm 0.5$ & 32.2 \\
\hline \multicolumn{5}{|l|}{ No. of corpora lutea (CL) } \\
\hline 0 & 91 & $25.3^{6}$ & $15.9 \pm 0.5^{5}$ & 23.6 \\
\hline 1 & 117 & 6.8 & $13.6 \pm 0.4$ & 29.1 \\
\hline 2 or more & 27 & 14.8 & $12.2 \pm 0.7$ & 37.0 \\
\hline \multicolumn{5}{|l|}{ Total no. of follicles $\geq 5 \mathrm{~mm}$} \\
\hline 1 & 59 & $0.0^{5}$ & $14.2 \pm 0.5$ & 33.9 \\
\hline 2 & 100 & 10.0 & $13.8 \pm 0.4$ & 30.5 \\
\hline 3 or more & 76 & 32.9 & $13.8 \pm 0.5$ & 20.0 \\
\hline \multicolumn{5}{|l|}{ Lactation number } \\
\hline 0 & 13 & 0.0 & $14.2 \pm 0.9^{6}$ & 30.8 \\
\hline 1 & 81 & 16.0 & $13.4 \pm 0.4$ & 27.5 \\
\hline 2 & 74 & 12.2 & $13.4 \pm 0.4$ & 29.4 \\
\hline 3 or more & 67 & 19.4 & $14.7 \pm 0.4$ & 26.1 \\
\hline \multicolumn{5}{|l|}{ Season } \\
\hline Winter & 78 & 14.1 & $14.0 \pm 0.4^{\mathrm{b}}$ & $33.3^{\mathrm{a}}$ \\
\hline Spring & 54 & 7.4 & $14.7 \pm 0.5^{b}$ & $38.0^{\mathrm{a}}$ \\
\hline Summer & 65 & 24.6 & $12.8 \pm 0.4^{\mathrm{a}}$ & $7.8^{\mathrm{b}}$ \\
\hline Autumn & 38 & 10.5 & $14.2 \pm 0.6^{\mathrm{b}}$ & $37.8^{\mathrm{a}}$ \\
\hline \multicolumn{5}{|c|}{${ }^{\mathrm{a}, \mathrm{b}}$ Means having different superscript letters differ $(P \leq 0.05)$. } \\
\hline \multicolumn{5}{|c|}{${ }^{1}$ Factors assessed at the not-pregnant diagnosis $(\mathrm{d} 0)}$. \\
\hline \multicolumn{5}{|c|}{${ }^{2}$ Number of observations (includes multiple observations of the same females). } \\
\hline \multicolumn{5}{|c|}{${ }^{3}$ Females that ovulated 1 or more follicles in response to the first GnRH injection. } \\
\hline \multirow{4}{*}{\multicolumn{5}{|c|}{$\begin{array}{l}{ }^{4} \text { Blood samples were collected at not-pregnant diagnosis }(\mathrm{d} 0) \text { and at } \mathrm{d} 7 \mathrm{and} 9\left(2 \mathrm{~d} \text { after } \mathrm{PGF}_{2 \alpha} \text { injection). }\right. \\
\text { In the first } 2 \text { blood samples, serum progesterone was classified as high }(\geq 1 \mathrm{ng} / \mathrm{mL}) \text { or low }(<1 \mathrm{ng} / \mathrm{mL}) \text {. } \\
\text { Anestrous cows had no CL at the not-pregnant diagnosis and low progesterone in all } 3 \mathrm{blood} \text { samples, } \\
\text { whereas proestrus to metestrus = low-high, early diestrus = high-high, and late diestrus = high-low. Cystic } \\
\text { diagnosis was based on scanned structure }>25 \mathrm{~mm} \text { in diameter and absence of a CL. Largest follicle excluded } \\
\text { the cystic structure. }\end{array}$}} \\
\hline & & & & \\
\hline & & & & \\
\hline & & & & \\
\hline \multicolumn{5}{|l|}{${ }^{5}$ Linear $(P \leq 0.001)$. } \\
\hline${ }^{6}$ Quadratic $(P \leq 0.06)$ & & & & \\
\hline
\end{tabular}

cles, and lactation number were without effect. All diestrous females that ovulated (single or multiple) in response to the first GnRH injection, however, tended $(P=0.15)$ to conceive at a greater rate than those first diagnosed in proestrus to metestrus $(32.3 \%, \mathrm{n}=133 \mathrm{vs}$. $22.2 \%, \mathrm{n}=102$ ). This tendency is consistent with greater pregnancy rates for cows initiating the Ovsynch protocol in early diestrus (Vasconcelos et al., 1999) or after Presynch-induced early diestrus (Moreira et al., 2001; El-Zarkouny et al., 2004).

\section{Ovulated Follicles}

Diameter of the largest ovulatory follicle in response to GnRH injection in single- and multiple-ovulating females was affected by number of CL, lactation number, and season (Table 4). As the number of CL present at GnRH injection increased, diameter of the ovulated follicle decreased $(P<0.05)$ linearly. Largest follicles that ovulated were smaller $(P<0.05)$ during summer than during other seasons (Table 4). Diameters of the largest follicle that ovulated did not differ among days of the estrous cycle (Figure 2). Size of the ovulatory follicle decreased (quadratic; $P<0.05$ ) initially in firstand second-lactation cows from that in replacement heifers and then increased in older cows (Table 4).

\section{Progesterone}

Concentrations of progesterone in serum at the first GnRH injection were affected (linear; $P<0.001$ and quadratic; $P<0.001$ ) by number of $\mathrm{CL}$ and total number of follicles $\geq 5 \mathrm{~mm}$ in diameter. As the number of CL increased from 0 to 2 or more, concentrations of progesterone increased $(0.6 \pm 0.2, \mathrm{n}=162 ; 3.5 \pm 0.2, \mathrm{n}=304$; and $5.1 \pm 0.3 \mathrm{ng} / \mathrm{mL}, \mathrm{n}=83$ ), respectively, and differed $(P<0.01)$ among cows having 0,1 , and 2 or more CL. Moreover, concentrations $(\mathrm{ng} / \mathrm{mL})$ of progesterone in- 
creased $(P<0.01)$ linearly as the number of CL increased from $1 \mathrm{CL}(3.7 \pm 0.2, \mathrm{n}=250)$, to $2 \mathrm{CL}(4.2 \pm$ $0.3, \mathrm{n}=176)$, to $3 \mathrm{CL}(5.8 \pm 0.5, \mathrm{n}=33)$, and to 4 $\mathrm{CL}(7.0 \pm 1.4, \mathrm{n}=5)$. In contrast, in a recent study of spontaneously ovulating nonlactating cows, tissue and plasma concentrations of progesterone on d 5 and 8 of the estrous cycle did not differ between cows having single and double CL, whereas weight of individual CL was less for double than single CL on both days (Mann et al., 2007).

As the number of follicles at the time of $\mathrm{GnRH}$ injection increased from 0 to 3 or more, progesterone increased $(P<0.05 ; 1.1 \pm 0.5, \mathrm{n}=28 ; 3.6 \pm 0.2, \mathrm{n}=191$; $3.9 \pm 0.2, \mathrm{n}=212 ; 3.8 \pm 0.3 \mathrm{ng} / \mathrm{mL}, \mathrm{n}=118)$, respectively. Females that ovulated in response to the first GnRH injection had less $(P<0.05)$ progesterone in serum than those that did not ovulate $(2.4 \pm 0.2 \mathrm{ng} / \mathrm{mL}, \mathrm{n}=314 \mathrm{vs}$. $3.7 \pm 0.2 \mathrm{ng} / \mathrm{mL}, \mathrm{n}=235$ ), respectively. Of females that ovulated more than 1 follicle in response to $\mathrm{GnRH}$, concentrations of progesterone did not differ from that of single-ovulating cows $(2.0 \pm 0.4 \mathrm{ng} / \mathrm{mL}, \mathrm{n}=35$ vs. 2.6 $\pm 0.2 \mathrm{ng} / \mathrm{mL}, \mathrm{n}=200$ ).

Cattle having concentrations of progesterone $\geq 1 \mathrm{ng} /$ $\mathrm{mL}$ at the first GnRH injection (not-pregnant diagnosis) had similar pregnancy rates to those having progesterone $<1 \mathrm{ng} / \mathrm{mL}(20.5 \%, \mathrm{n}=434$ vs. $21.1 \%, \mathrm{n}=228)$. In contrast, those having elevated progesterone $7 \mathrm{~d}$ later (immediately before $\mathrm{PGF}_{2 \alpha}$ injection) had greater $(P<$ $0.01)$ pregnancy rates than those having progesterone $<1 \mathrm{ng} / \mathrm{mL}(24.3 \%, \mathrm{n}=503$ vs. $8.2 \%, \mathrm{n}=159)$, respectively. Further, concentrations of serum progesterone at the time of $\mathrm{PGF}_{2 \alpha}$ injection were greater $(P<0.05)$ in those cows that subsequently became pregnant after TAI than in those that did not conceive $(4.6 \pm 0.3 \mathrm{ng} /$ $\mathrm{mL}, \mathrm{n}=135$ vs. $3.4 \pm 0.1 \mathrm{ng} / \mathrm{mL}, \mathrm{n}=534$ ), respectively.

\section{Luteolysis}

Concentrations of progesterone in females on $\mathrm{d} 7 \mathrm{in}$ which at least $1 \mathrm{CL}$ was present before the injection of $\mathrm{PGF}_{2 \alpha}$ are illustrated in Figure 3 (upper panel). Concentrations of progesterone among cows having 1,2 , or 3 or more CL differed $(P<0.05)$ from one another and increased linearly $(P<0.01)$ with increasing number of CL. Regression of CL in response to $\mathrm{PGF}_{2 \alpha}$ did not differ among females having 1 or more CL (Figure 3; lower panel). When regression was assessed by the proportion of cows in which concentrations of progesterone decreased from $\geq 1 \mathrm{ng} / \mathrm{mL}$ at the time of $\mathrm{PGF}_{2 \alpha}$ injection to $<1 \mathrm{ng} / \mathrm{mL} 48 \mathrm{~h}$ later, proportions of cows in which luteolysis occurred were numerically slightly more for those having $1 \mathrm{CL}(88 \%)$ than for those having 2 $(82.5 \%)$, or 3 or more CL (82.1\%). Some cows conceived having no luteal regression because progesterone de-
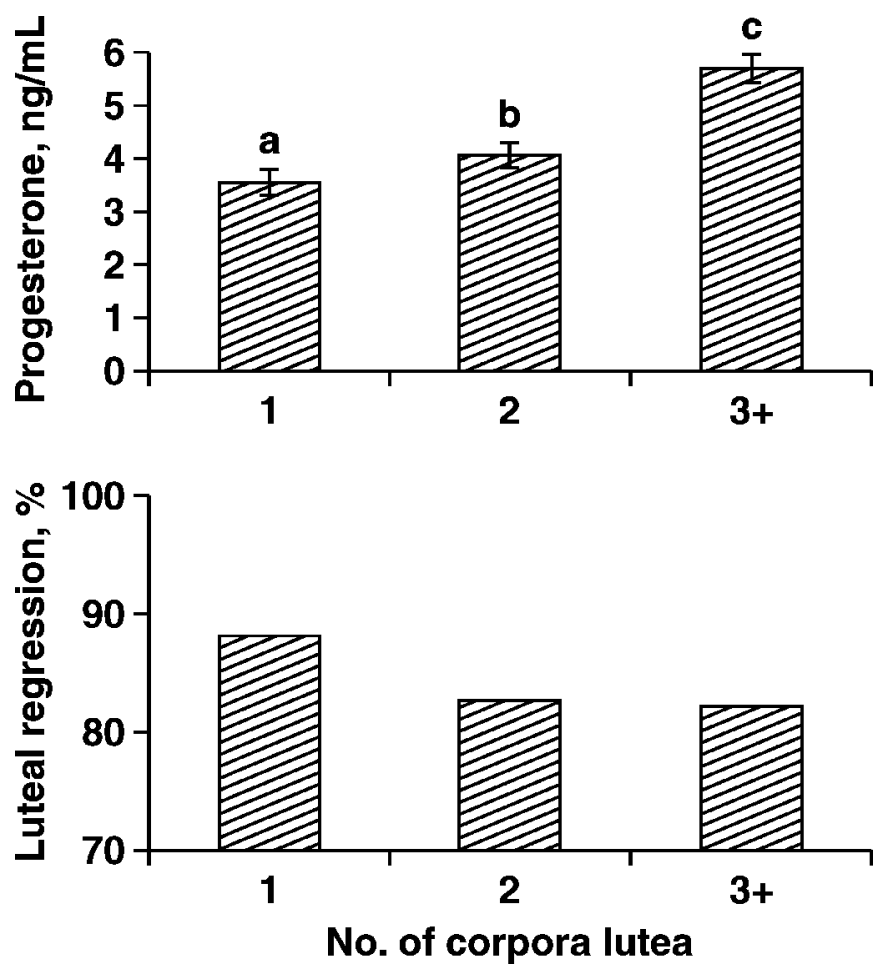

Figure 3. Concentrations of progesterone before injection of $\mathrm{PGF}_{2}$ (d 7) in dairy cattle having $1(\mathrm{n}=258), 2(\mathrm{n}=183)$, or 3 or more $(\mathrm{n}=$ 39) luteal structures detected by transrectal ultrasonography before $\mathrm{PGF}_{2 \alpha}$ injection and proportion of corpora lutea (CL) that underwent regression (serum progesterone $\geq 1 \mathrm{ng} / \mathrm{mL}$ before $\mathrm{PGF}_{2 \alpha}$ and $<1 \mathrm{ng} /$ $\mathrm{mL} 48 \mathrm{~h}$ later $).{ }^{\mathrm{a}-c}$ Bars not sharing a common letter differ $(P \leq 0.05)$.

creased after $\mathrm{PGF}_{2 \alpha}$ injection, but not to $<1 \mathrm{ng} / \mathrm{mL}$ by $48 \mathrm{~h}$ (Table 1).

In summary of TAI pregnancy rates, females initiating the Ovsynch protocol in proestrus to metestrus or early diestrus and having successful luteolysis in response to $\mathrm{PGF}_{2 \alpha}, 7 \mathrm{~d}$ after a not-pregnancy diagnosis had the greatest pregnancy rates (Table 4) and the greatest ovulation incidence after the first GnRH injection compared with those having other ovarian-luteal statuses. Females in late diestrus at the not-pregnant diagnosis in which early luteolysis occurred, those in proestrus to metestrus in which the CL failed to regress, and those having apparent anestrus or anovulation (reduced concentrations of progesterone on d 0,7 , and 9) were poor candidates for successful TAI.

\section{ACKNOWLEDGMENTS}

We express appreciation to the dairy staff at the Kansas State University Dairy Teaching and Research Center for their assistance in conducting this study. We thank Irene Vanderwerff for her laboratory assistance. 


\section{REFERENCES}

Blevins, C. A., J. E. Shirley, and J. S. Stevenson. 2006. Milking frequency, estradiol cypionate, and somatotropin influence lactation and reproduction in dairy cows. J. Dairy Sci. 89:4176-4187.

Brusveen, D. J., A. P. Cunha, C. D. Silva, P. M. Cunha, R. A. Sterry, E. P. B. Silva, J. N. Guenther, and M. C. Wiltbank. 2006. Effects on conception rate of lactating dairy cows by altering the time of the second GnRH and AI during Ovsynch. J. Dairy Sci. 89(Suppl. 1):150. (Abstr.)

Echternkamp, S. E. 2000. Endocrinology of increased ovarian folliculogenesis in cattle selected for twin births. Proc. Am. Soc. Anim. Sci. 1999. Accessed at http://www.asas.org/JAS/symposia/proceedings/0935.pdf

Echternkamp, S. E., A. J. Roberts, D. D. Lunstra, T. Wise, and L. J. Spicer. 2004. Ovarian follicular development in cattle selected for twin ovulations and births. J. Anim. Sci. 82:459-471.

El-Zarkouny, S. Z., J. A. Cartmill, B. A. Hensley, and J. S. Stevenson. 2004. Pregnancy in dairy cows after synchronized ovulation regimens with and without presynchronization and progesterone. J. Dairy Sci. 87:1024-1037.

Fricke, P. M., and M. C. Wiltbank. 1999. Effect of milk production on the incidence of double ovulation in dairy cows. Theriogenology 52:1133-1143.

Ginther, O. J., M. A. Beg, F. X. Donadeu, and D. R. Bergfelt. 2003. Mechanism of follicle deviation in monovular farm species. Anim. Reprod. Sci. 78:239-257.

Gümen, A., J. N. Guenther, and M. C. Wiltbank. 2003. Follicular size and response to Ovsynch versus detection of estrus in anovular and ovular lactating dairy cows. J. Dairy Sci. 86:3184-3194.

Lucy, M. C., J. D. Savio, L. Badinga, R. L. De La Sota, and W. W. Thatcher. 1992. Factors that affect ovarian follicular dynamics in cattle. J. Anim. Sci. 70:3615-3626.
Mann, G. E., R. S. Robinson, and M. G. Hunter. 2007. Corpus luteum size and function following single and double ovulations in nonlactating dairy cows. Theriogenology 67:1256-1261.

Moreira, F., C. Orlandi, C. A. Risco, R. Mattos, F. Lopes, and W. W. Thatcher. 2001. Effects of presynchronization and bovine somatotropin on pregnancy rates to a timed artificial insemination protocol in lactating dairy cows. J. Dairy Sci. 84:1646-1659.

NRC. 2001. Nutrient Requirements of Dairy Cattle. 7th rev. ed. Natl. Acad. Sci., Washington, DC.

Portaluppi, M. A., and J. S. Stevenson. 2005. Pregnancy rates in lactating dairy cows after presynchronization of estrous cycles and variations of the Ovsynch protocol. J. Dairy Sci. 88:914-921.

Pursley, J. R., M. W. Kosorok, and M. C. Wiltbank. 1997. Reproductive management of lactating dairy cows using synchronization of ovulation. J. Dairy Sci. 80:301-306.

Pursley, J. R., M. O. Mee, and M. C. Wiltbank. 1995. Synchronization of ovulation in dairy cows using $\mathrm{PGF}_{2 \alpha}$, and GnRH. Theriogenology 44:915-923.

Royal, M. D., A. O. Darwash, R. Webb, A. P. F. Flint, J. A. Woolliams, and G. E. Lamming. 2000. Declining fertility in dairy cattle: Changes in traditional and endocrine parameters of fertility. Anim. Sci. 70:487-500.

Skaggs, C. L., B. V. Able, and J. S. Stevenson. 1984. Pulsatile or continuous infusion of luteinizing hormone-releasing hormone and hormonal concentrations in prepubertal beef heifers. J. Anim. Sci. 62:1034-1048.

Vasconcelos, J. L. M., R. W. Silcox, G. J. Rosa, J. R. Pursley, and M. C. Wiltbank. 1999. Synchronization rate, size of the ovulatory follicle, and pregnancy rate after synchronization of ovulation beginning on different days of the estrous cycle in lactating dairy cows. Theriogenology 52:1067-1078.

Wiltbank, M. C., P. M. Fricke, S. Sangsritavong, R. Sartori, and O. J. Ginther. 2000. Mechanisms that prevent and produce double ovulations in dairy cattle. J. Dairy Sci. 83:2998-3007. 